\title{
Detection of herbaceous-plant pararetrovirus in lichen herbarium samples
}

\author{
K. PETRZIK ${ }^{1}$, I. KOLONIUK ${ }^{1}$, T. SARKISOVÁ ${ }^{1}$, L. ČÍHAL ${ }^{2}$
}

\begin{abstract}
${ }^{1}$ Department of Plant Virology, Institute of Plant Molecular Biology, Biology Centre of the Academy of Sciences of the Czech Republic, Branišovská 31, 37005 České Budějovice, Czech Republic; ${ }^{2}$ Silesian Museum, Nádražní okruh 31, 74601 Opava, Czech Republic

Received July 23, 2015; revised September 4, 2015; accepted April 19, 2016

Summary. - Cauliflower mosaic virus (CaMV) - a plant pararetrovirus that naturally causes diseases in Brassicaceae and Solanaceae plant hosts worldwide - has been detected by PCR for the first time in herbarium samples of Usnea sp. lichens. The virus's presence in these lichens did not result in any micro- or macromorphological changes, and the herbarium records were classified as representative for the distinct species. Sequence analyses classified all the detected viruses into one lineage of CaMV isolates. We have shown here that herbarium samples could be a good source for virus study, especially where a longer time span is involved.
\end{abstract}

Keywords: cauliflower mosaic virus; dsDNA; pararetrovirus; persistent virus

\section{Introduction}

Lichen thallus may be inhabited by a plethora of such animals as tardigrades, rotifers, nematodes (Sohlenius et al., 2004), and microarthropods (Materna, 2000) along with protozoans (Bamforth, 2004), epiphytic fungi (Lawrey and Diederich, 2003; Suryanarayanan et al., 2005), and a wide range of bacteria (Bates et al., 2011; Muggia et al., 2013). In addition to the lichen-forming associations between symbiotic fungi and a photosynthesizing organism, a number of endolichenic fungi grow in association with algal photobionts inside asymptomatic lichen thalli and resemble fungal endophytes of plants (Arnold, 2007; He and Zhang 2012). Despite the complexity of the lichen biome, until recently no virus has been described in lichen fungus, in its photobiont, or in any other accompanying organism while performing control or balancing functions. Nevertheless, more than 200 viruses have been described in fungi ( 89 complete genomes and about 120 partial genomes; GenBank, Mar. 2015), as have been numerous cyanophages in cyanobacteria, (14 complete genomes, about 400 partial genomes), and unique large DNA viruses in algae ( 40 complete genomes, about 200 partial genomes).

E-mail: petrzik@umbr.cas.cz; phone: +420-387-775-549.

Abbreviations: $\mathrm{CaMV}=$ cauliflower mosaic virus
There are assumed to be no viruses of angiosperms that are able to infect primitive nonvascular plants (e.g. mosses) under natural conditions, and no plant virus has been isolated from a nonvascular plant growing in the wild. Nevertheless, tobacco mosaic virus and cucumber green mottle mosaic tobamovirus' antigens have been detected by ELISA in arctic Barbilophozia and Polytrichum mosses (Polischuk et al., 2007). In a laboratory experiment, it was proven that Physcomitrella patens moss supported multiplication of Tomato spotted wilt virus (Hühns et al., 2003). In addition, highly effective Agrobacterium tumefaciens transformation of the lichen fungus Umbilicaria muehlenbergii performed by mixing and cocultivation opens the possibility for how lichen could be transformed or infected in the wild (Park et al., 2013). Recently, plant-infecting Apple mosaic virus (a segmented virus with positive ssRNA genome from the genus Ilarvirus) and putative cytorhabdovirus (with negative ssRNA genome) have been detected in Usnea, Cladonia, Pseudevernia, Xanthoria, and Lasallia sp. (Petrzik et al., 2014). Furthermore, complete genome of plant CaMV (a pararetrovirus with a circular dsDNA genome) has been sequenced from lichen photobiont Trebouxia sp. and CaMV was detected in free-living fresh water algae from the Chlorellales, Prasiolales, Microthamniales, and Oocystales orders, thus indicating a wider range of hosts for this virus than had been previously assumed (Petrzik et al., 2015). 
CaMV was the first plant virus to be discovered to contain DNA as genetic material and the first virus to be sequenced completely (Franck et al., 1980). It is disseminated worldwide wherever its hosts are planted and is transmitted by several aphid species. Transmission by other vector types or by pollen has never been reported in nature, although CaMV can readily be transmitted by infected sap to a mechanically injured host plant (Blanc et al., 2001). Members of the Brassicaceae (cabbage family) have been reported as systemic plant hosts, but B29, W260, Japan-S, and NY8153 CaMV isolates are able to infect also the Solanaceae (nightshade family) species Nicotiana clevelandii (wild Cleveland's tobacco) and Datura stramonium (Jimson weed) (Haas et al., 2002). Sequence analysis of a large set of CaMV isolates from geographically distant locations recently showed that this virus probably spread from a single population in Turkey around 400-500 years ago and is known in four geographically distributed lineages (Yasaka et al., 2014).

In this paper, we describe for the first time Usnea lichens as new hosts of CaMV and show herbarium records to be a suitable source for virus molecular analysis.

Table 1. Lichen samples used in this study

\begin{tabular}{|c|c|c|c|c|c|c|c|c|c|}
\hline Lichen & $\begin{array}{c}\text { SM OP } \\
\text { catalogue } \\
\text { No. }\end{array}$ & $\begin{array}{c}\text { Year of } \\
\text { collection }\end{array}$ & $\begin{array}{c}\text { Country/place } \\
\text { of origin }\end{array}$ & $\begin{array}{c}\text { Sequence } \\
\text { length (nt) }\end{array}$ & $\begin{array}{c}\text { Localization } \\
\text { on CaMV } \\
\text { genome }^{*}\end{array}$ & $\begin{array}{l}\text { GenBank } \\
\text { Acc. No. }\end{array}$ & $\begin{array}{c}\text { Blastn } \\
\text { E-value/ } \\
\text { mostly } \\
\text { related } \\
\text { sequence \% }\end{array}$ & $\begin{array}{c}\text { Blastx } \\
\text { E-value/ } \\
\text { mostly } \\
\text { related } \\
\text { sequence \% }\end{array}$ & $\begin{array}{c}\text { CaMV } \\
\text { presence }\end{array}$ \\
\hline Usnea amaliae & 10734 & 1961 & $\begin{array}{l}\text { Uruguay, } \\
\text { Maldonado }\end{array}$ & - & - & - & - & - & - \\
\hline Usnea barbata & 134472 & 1848 & North Wales & - & - & - & - & - & - \\
\hline Usnea cavernosa & 142754 & 1952 & $\begin{array}{l}\text { USA, New } \\
\text { Mexico, Spirit Lake }\end{array}$ & - & - & - & - & - &,$+ \mathrm{NS}$ \\
\hline Usnea cladocarpa & 164797 & 1978 & $\begin{array}{l}\text { Brasilia, Serra da } \\
\text { Mantiqueira }\end{array}$ & 349 & $908-1256$ & KP292822 & $\begin{array}{c}0.0 \\
\text { KF550287 } \\
100 \% \\
\end{array}$ & $\begin{array}{c}1 \mathrm{e}-82 \\
\text { KF550287 } \\
100 \% \\
\end{array}$ & + \\
\hline Usnea fasciata & 117262 & 1946 & $\begin{array}{l}\text { Falkland Islands, } \\
\text { Port Stanley }\end{array}$ & - & - & - & - & - &,$+ \mathrm{NS}$ \\
\hline Usnea gigas & 162660 & 1937 & Zaire, Yangambi & - & - & - & - & - & - \\
\hline Usnea hawaiiensis & 102211 & 1964 & $\begin{array}{l}\text { USA, Hawaii, } \\
\text { Lanai }\end{array}$ & $\begin{array}{l}349 \\
336\end{array}$ & $\begin{array}{l}908-1256 \\
7014-7349\end{array}$ & $\begin{array}{l}\text { KP292820 } \\
\text { KP292824 }\end{array}$ & $\begin{array}{c}3 \mathrm{e}-178 \\
\text { KF550287 } \\
99 \% \\
3 \mathrm{e}-174 \\
\text { KF550287 } \\
99 \%\end{array}$ & $\begin{array}{c}2 \mathrm{e}-80 \\
\text { KF550287 } \\
98 \% \\
3 \mathrm{e}-70 \\
\text { KF550287 } \\
99 \%\end{array}$ & + \\
\hline Usnea longissima & 170728 & 1986 & $\begin{array}{l}\text { Abkhazia, } \\
\text { Sukhumi }\end{array}$ & 748 & $3616-4363$ & KР292819 & $\begin{array}{c}0.0 \\
\text { KF550287 } \\
99 \% \\
\end{array}$ & $\begin{array}{c}2 \mathrm{e}-180 \\
\text { KF550287 } \\
100 \% \\
\end{array}$ & + \\
\hline Usnea marocana & 125543 & 1970 & France, Port-Cros & - & & - & - & - & - \\
\hline Usnea osseina & 123586 & 1969 & $\begin{array}{l}\text { Tanzania, } \\
\text { Uluguru Mts. }\end{array}$ & 386 & $2318-2703$ & KP292823 & $\begin{array}{c}0.0 \\
\text { KM502557 } \\
100 \%\end{array}$ & $\begin{array}{c}5 e-66 \\
\text { KM502557 } \\
100 \%\end{array}$ & + \\
\hline Usnea scabrata & 100726 & 1959 & $\begin{array}{l}\text { Canada, Saskatch- } \\
\text { ewan, Beaver Lake }\end{array}$ & 349 & $908-1256$ & KP292821 & $\begin{array}{c}3 \mathrm{e}-178 \\
\text { KF550287 } \\
99 \%\end{array}$ & $\begin{array}{c}9 \mathrm{e}-81 \\
\text { KF550287 } \\
98 \%\end{array}$ & + \\
\hline Usnea simplicissima & 150412 & 1976 & $\begin{array}{l}\text { Tanzania, } \\
\text { Kilimanjaro }\end{array}$ & - & - & - & - & - & - \\
\hline Usnea squarrosa & 168692 & 1975 & Indonesia, Java & - & - & - & - & - &,$+ \mathrm{NS}$ \\
\hline Usnea sulphurea & 124272 & 1967 & $\begin{array}{l}\text { Iceland, } \\
\text { Tungnafellsjokull }\end{array}$ & 744 & $3617-4363$ & KP292818 & $\begin{array}{c}0.0 \\
\text { KF498706 } \\
99 \%\end{array}$ & $\begin{array}{c}8 \mathrm{e}-174 \\
\text { KF498706 } \\
99 \%\end{array}$ & + \\
\hline Usnea tanzanica & 147838 & 1972 & Tanzania, Rungwe & - & - & - & - & - & - \\
\hline Usnea welwischiana & 153490 & 1968 & Kenya, Tsavo & - & - & - & - & - & - \\
\hline
\end{tabular}

"Numbering according to isolate 219-1d sequence, GenBank Acc. No. KF550287. KM502557 = CaMV isolate from Graesiella vacuolata, KF498706 = CaMV isolate CB1 from cauliflower, NS = not sequenced. 


\section{Material and Methods}

Material. Lichen samples collected between 1848 and 1986 at different locations were obtained from Silesian Museum's lichen herbarium, Opava, Czech Republic (SM OP) (Table 1). The lichens had been stored in paper envelopes and maintained in a temperature- and humidity-controlled location. All the samples were analysed twice, using different DNA isolation methods, at different time.

Nucleic acid isolation and transcription. Before extraction, $100 \mathrm{mg}$ of lichen thallus was pulverized in liquid nitrogen. First, a DNA plant kit (Macherey Nagel, Germany) was used according to the manufacturer's recommendation. This approach included degradation of contaminating RNA with 15 min of RNase treatment. DNA was ethanol precipitated, then dissolved in $20 \mu \mathrm{l}$ of sterile water. Second, the DNA was isolated using a Wizard Magnetic DNA plant system kit (Promega Corporation, USA) and dissolved in $20 \mu \mathrm{l}$ of sterile water. Total RNA was isolated from the same amount of sample using Plant RNA mini spin kit (Macherey Nagel, Germany). Contaminating DNA was on-column degraded with DNase digestion for $15 \mathrm{~min}$. The RNA was ethanol precipitated and dissolved in $10 \mu \mathrm{l}$ of sterile water. First strand cDNA was synthesized from the total amount of isolated RNA using the SuperScript III First-strand synthesis system (Life Technologies Corp.) according to the manufacturer's protocol.

CaMV screening. Virus screening was performed using five pairs of CaMV-specific primers (Table 2). The primers hybridize to gene I (Ca750 and Ca751), gene IV (Ca355 and Ca356), gene V (Ca470 and Ca476, Ca465 and Ca478), and a 35 S promoter (Ca390 and Ca335) (Table 2). For PCR amplification, $2.5 \mathrm{U}$ of DreamTaq DNA polymerase (Thermo Scientific), $2 \mathrm{mmol} / 1 \mathrm{MgCl}_{2}, 0.2 \mathrm{mmol} / \mathrm{l}$ of each dNTP, 200 $\mathrm{nmol} / \mathrm{l}$ of each primer, and $1 \mu \mathrm{l}$ of isolated DNA or $2 \mu \mathrm{l}$ of cDNA were mixed in a $20 \mu \mathrm{l}$ reaction and 35 cycles were performed. Amplified products were agarose gel separated, stained with SybrGreen and then visualized under UV light. Bands of expected size were excised, gel extracted using a NucleoSpin Extract II kit (Macherey Nagel, Germany), cloned and sequenced using the BigDye Terminator v3.1 Cycle sequencing kit (Life Technologies, USA). Nucleotide sequences and their in silico transcribed amino acid sequences were compared using blastn and blastp with GenBank data.

\section{Results and Discussion}

More than 50 herbarium samples 20-100 years old were tested for CaMV presence over the past 3 years in our laboratory. Not all primer pairs used for CaMV screening resulted in a visible amount of amplicons of expected size, however, even though they work with nucleic acid from infected plant host (Fig. 1). Primer pair Ca750/Ca751 producing the shortest amplicon from gene I and pair Ca390/Ca335 for 35S promotor sequence were the most effective, amplifying three and two templates, respectively. On the other hand, Ca355/ Ca356 and Ca390/Ca335 pairs amplified one template each and Ca465/Ca478 produced no visible product with any sample. To date, CaMV was detected with at least one pair of primers in 9 of 16 Usnea samples (Table 1). The oldest CaMV-positive sample has been collected 62 years ago. Blastn and blastx comparison of those nucleotide sequences obtained with GenBank identified the Cauliflower mosaic virus nature of these sequences with the best expected value of all alignments from that database sequences (E-value close to zero) (Table 1). The CaMV 219-1d isolate from Trebouxia sp. lichen photobiont was recognized as the most closely

Table 2. CaMV detection primers

\begin{tabular}{|c|c|c|c|c|}
\hline Primer & Sequence & Localization on CaMV genome ${ }^{*}$ & Annealing & $\begin{array}{r}\text { Expected } \\
\text { product }\end{array}$ \\
\hline Ca750 & 5'-CAGCCAAAGGTAATCTCGCA-3' & \multirow[b]{2}{*}{$864-1256$ gene I } & \multirow[b]{2}{*}{$55^{\circ} \mathrm{C}$} & \multirow[b]{2}{*}{393 bp } \\
\hline Ca751 & 5'-CATTGTTTCCTATTTGAAGACTATTACC-3' & & & \\
\hline Ca355 & 5'-ACCAAATTATTGATCTAACC-3' & \multirow[b]{2}{*}{ 2318-2739 gene IV (capsid protein) } & \multirow[b]{2}{*}{$45^{\circ} \mathrm{C}$} & \multirow[b]{2}{*}{422 bp } \\
\hline Ca356 & 5'-AAGATAGTCTTCTCTATTGG-3' & & & \\
\hline $\mathrm{Ca} 470$ & 5'-TTTAACCTTGATAGCTTTGCTTG-3' & \multirow[b]{2}{*}{$3581-4363$ gene $\mathrm{V}$} & \multirow[b]{2}{*}{$50^{\circ} \mathrm{C}$} & \multirow[b]{2}{*}{783 bp } \\
\hline $\mathrm{Ca} 476$ & 5'-TAGAATACAAAGAAGAGGAAGAAGA-3' & & & \\
\hline $\mathrm{Ca} 465$ & 5'-AGCAATGACAAAGAGACACTGG-'3 & \multirow{2}{*}{ 5387-6053 gene V-VI } & \multirow[b]{2}{*}{$55^{\circ} \mathrm{C}$} & \multirow[b]{2}{*}{$667 \mathrm{bp}$} \\
\hline $\mathrm{Ca} 478$ & 5'-TAGCCTTGTCCCAGTCTGAAC-'3 & & & \\
\hline Ca390 & 5'-AGGACCTAACAGAACTCGCCG-3 & \multirow[b]{2}{*}{ 7012-7392 promotor } & \multirow[b]{2}{*}{$50^{\circ} \mathrm{C}$} & \multirow[b]{2}{*}{$381 \mathrm{bp}$} \\
\hline Ca335 & 5'-TAGAGGAAGGGTCTTGCGAAGG-3' & & & \\
\hline
\end{tabular}

*Numbering as in Table 1 


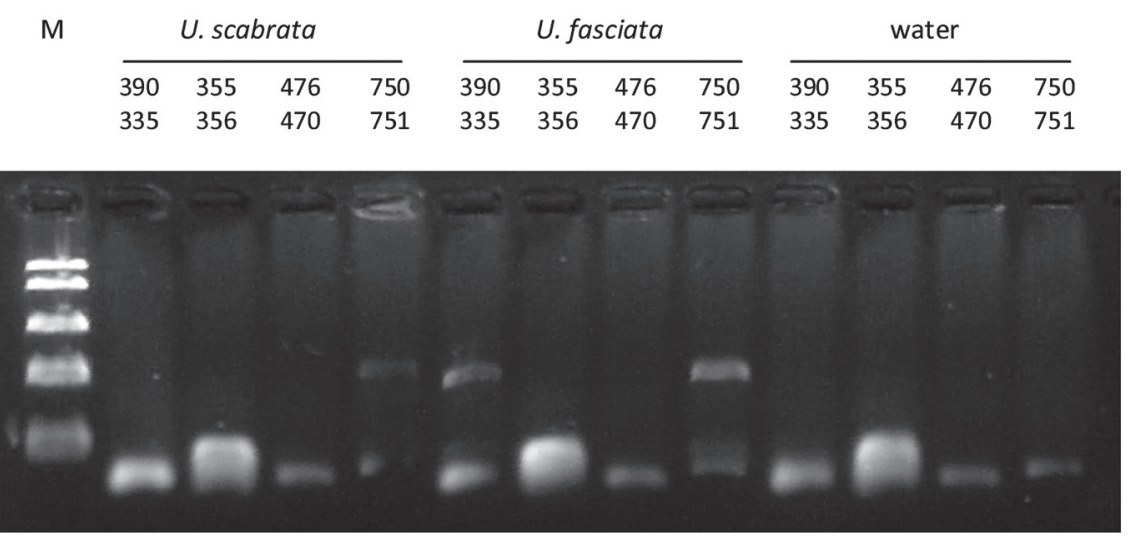

Fig. 1

CaMV detection in Usnea scabrata 100726 and U. fasciata 117262 with primers Ca390/Ca335 (381 bp product expected), Ca355/Ca356 (422 bp), Ca476/Ca470 (783 bp), and Ca750/Ca751 (393 bp)

M - FastRuller Middle Range DNA ladder of 5 kbp, 2 kbp, 850 bp, 400 bp, $100 \mathrm{bp}$ (LifeTechnologies).

related (more than $98 \%$ nt or amino acid identity) to Usnea cladocarpa, U. hawaiiensis, U. longissima, and U. scabrata samples, sequence from U. osseina was identical with CaMV from Graesiella vacuolata algae. Sequence from U. sulphurea was 99\% identical to that of CaMV isolate CB1 from cauliflower. The sequences were deposited in GenBank under AC numbers KP29218-24. We performed an infectivity test and mechanically inoculated Chinese cabbage with homogenate of $U$. fasciata, U. longissima, and U. sulphurea. No disease symptoms developed and CaMV was not detected in the plants. We concluded that the viral genome had most probably been damaged during lichen storage and that the lichens no longer contained the virus in infectious form.

It has been reported that samples up to 35 years old have been used routinely for successful DNA extraction (Grube et al., 1995) and that rDNA was amplified from herbarium samples of lichens more than 150 years old (Hawksworth, 2013). To obtain viral DNA of the highest possible quality from lichens, two different protocols were used: the Wizard system using paramagnetic particles (which is recommended for isolation of DNA from leaves and seeds) and the NucleoSpin system based on the established CTAB/SDS lysis method (which is recommended for isolation from plants and fungi). Both methods resulted in amplifiable DNA from the Usnea samples we had, but DNA from the Wizard system could be amplified easily with more primers.

In the case of the Usnea herbarium samples, we did not detect CaMV from transcribed RNA of any CaMV-positive sample. We could assume that a) the viral RNA transcript was more prone to degradation than was the genomic DNA; b) not all photobionts are identically suitable for hosting CaMV, thus resulting in notable differences in virus fitness and replication; c) such environmental conditions as low or high temperature, water content, and others could influence the cohabitation of lichen with the virus; and d) nothing is known about virus acquisition by the lichens, duration of infection, or virus distribution and movement (if any) in lichen thallus.

We may hypothesize that lichens could be accidental hosts of this plant virus. On the other hand, Usnea spp. are longlived lichens and, in this case, they could be regular hosts of CaMV. In accordance with previous findings (Petrzik et al., 2014, 2015), we suggest that lichens could serve as reservoirs for plant viruses, despite the fact that the mechanism of transmission among lichens themselves or among different organisms is not clear, and that herbarium samples constitute a good source for molecular study of viruses.

Acknowledgements. This work was conducted with support from Czech Science Foundation project no. P501/12/1747 and institutional support RVO60077344 from the Biology Centre. The authors thank $O$. Kubešová for her excellent technical assistance.

\section{References}

Arnold AE (2007): Understanding the diversity of foliar endophytic fungi: progress, challenges, and frontiers. Fungal Biol. Rev. 21, 51-66. http://dx.doi.org/10.1016/j.fbr.2007.05.003

Bamforth SS (2004): Water film fauna of microbiotic crusts of a warm desert. J. Arid Environ. 56, 413-423. http://dx.doi. org/10.1016/S0140-1963(03)00065-X

Bates ST, Cropsey GWG, Caporaso JG, Knight R, Fierer N (2011): Bacterial communities associated with the lichen symbiosis. Appl. Environ. Microbiol. 77, 1309-1314. http:// dx.doi.org/10.1128/AEM.02257-10

Blanc S, Hébrard E, Drucker M, Froissart R (2001): Molecular aspects of virus-vector interactions: Caulimoviruses. In Harris K, Duffus JE, Smith OP (Eds): Virus-Insect-Plant 
Interactions. Academic Press, San Diego, pp. 143-167. http://dx.doi.org/10.1016/B978-012327681-0/50011-X

Franck A, Guilley H, Jonard G, Richards K, Hirth L (1980): Nucleotide sequence of cauliflower mosaic virus DNA Cell 21, 285-294. http://dx.doi.org/10.1016/0092-8674(80)90136-1

Grube M, DePriest PT, Gargas A, Hafellner J (1995): DNA isolation from lichen ascomata. Mycol. Res. 99, 1321-1324. http:// dx.doi.org/10.1016/S0953-7562(09)81215-X

Haas M, Bureau M, Geldreich A, Yot P, Keller M (2002): Cauliflower mosaic virus: still in the news. Mol. Plant. Pathol. 3, 419429. http://dx.doi.org/10.1046/j.1364-3703.2002.00136.x

Hawksworth DL (2013): The oldest sequenced fungal specimen. The Lichenologist 45, 131-132. http://dx.doi.org/10.1017/ $\underline{\text { S0024282912000710 }}$

He Y, Zhang Z (2012): Diversity of organism in the Usnea longissima lichen. Afr. J. Microbiol. Res. 6, 4797-4804.

Hühns S, Bauer C, Buhlmann S, Heinze C, von Bargen S, Paape M, Kellmann JW (2003): Tomato spotted wilt virus (TSWV) infection of Physcomitrella patens gametophores. Plant Cell Tiss. Org. 75, 183-187.

Lawrey JD, Diederich P (2003): Lichenicolous fungi: interactions, evolution, and biodiversity. The Bryologist 106, 80-120. http://dx.doi.org/10.1639/0007-2745(2003)106[0080:LFIEAB]2.0.CO;2

Materna J (2000): Oribatid communities (Acari: Oribatida) inhabiting saxicolous mosses and lichens in the Krkonoše Mts. (Czech Republic). Pedobiologia 44, 40-62. http://dx.doi. org/10.1078/S0031-4056(04)70027-X

Muggia L, Klug B, Berg G, Grube M (2013): Localization of bacteria in lichen from Alpine soil crust by fluorescence in situ hybridization. Appl. Soil Ecol. 68, 20-25. http://dx.doi. org/10.1016/j.apsoil.2013.03.008

Park S-Y, Jeong M-H, Wang H-Y, Kim JA, Yu N-H, Kim S, Cheong YH, Kang A, Lee Y-H, Hur J-S (2013): Agrobacterium tumefaciens-mediated transformation of the lichen fungus, Umbilicaria muehlenbergii. PLoS ONE 8, e83896. http://dx.doi.org/10.1371/journal.pone.0083896

Petrzik K, Vondrák J, Barták M, Peksa O, Kubešová O (2014): Lichens - a new source or yet unknown host of herbaceous plant viruses? Eur. J. Plant Pathol. 138, 549-559. http:// dx.doi.org/10.1007/s10658-013-0246-Z

Petrzik K, Vondrák J, Kvíderová J, Lukavský J (2015): Platinum anniversary: virus and lichen alga together more than 70 years. PLoS ONE 10, e0120768. http://dx.doi.org/10.1371/ journal.pone. 0120768

Polischuk V, Budzanivska I, Shevchenko T, Oliynik S (2007): Evidence for plant viruses in the region of Argentina islands, Antarctica. FEMS Microbiol. Ecol. 58, 409-417. http:// dx.doi.org/10.1111/j.1574-6941.2006.00242.x

Sohlenius B, Boström S, Jönsson KI (2004): Occurrence of nematodes, tardigrades and rotifers on ice-free areas in East Antarctica. Pedobiologia 48, 395-408. http://dx.doi. org/10.1016/j.pedobi.2004.06.001

Suryanarayanan TS, Thirunavukkarasu N, Hariharan GN, Balaji PQ (2005): Occurrence of non-obligate microfungi inside lichen thalli. Sydowia 57, 120-130.

Yasaka R, Nguyen HD, Ho SYW, Duchêne S, Korkmaz S, Katis N, Takahashi H, Gibbs AJ, Ohshima K (2014): The temporal evolution and global spread of Cauliflower mosaic virus, a plant pararetrovirus. PloS ONE 9, e85641. http://dx.doi. org/10.1371/journal.pone.0085641 